\title{
Surgical Management of Atresia recti-ani and coli in a Holstein Friesian Cross bred calf
}

\author{
R.V. Suresh Kumar, P.Veena, P. Sankar*, N. Dhana Lakshmi and S.Kokila \\ Department of Veterinary Surgery and Radiology College of Veterinary Science, \\ Sri Venkateswara Veterinary University, Tirupati-517502 (A.P) \\ * Corresponding author email : sansurvet@gmail.com
}

\section{I ntroduction}

Atresia coli is a lethal congenital abnormality in calves and other animals (Syed and Shanks, 1992). This condition is caused by an incomplete digestive tract, due to part of the colon being missing (Young et.al, 1992). Atresia recti and ani can occur simultaneously with atresia coli (Benamou et.al, 1995). The present paper describes a case of atresia coli with atresia recti and ani in a new born Holstein Friesian cross bred calf.

\section{Case History and Observation}

A three day old Holstein Friesian cross bred calf was presented to the Department of Veterinary Surgery and Radiology, College of Veterinary Science, Tirupathi (AP) with the history of lack of muconium and distended abdomen. Clinical examination revealed increased respiratory and heart rate but the temperature was normal. Distended abdomen (Figure1), lack of muconium in the rectal examination. Haemato-biochemical (Hb-13.0g/dl, $\mathrm{PCV}, 41 \%$, total protein- $6.5 \mathrm{~g} / \mathrm{dl}$, albumin$2.8 \mathrm{~g} / \mathrm{dl}$,globulin-3.7g/dl and AST-82Uits/L) values were within the normal range. Based on the history and clinical examination tentatively it was diagnosed as a case of atresia ani and surgical correction was planned.

\section{Treatment and Discussion}

Atresia ani was corrected by standard surgical procedure but the rectal cul-de-sac could not be located. Hydro-propulsion revealed backward flow of water and passage of lubricated catheter through the anus which resisted upto $15 \mathrm{~cm}$ and it was diagnosed as a case of atresia coli. The right flank was prepared for aseptic surgery and animal was placed on left lateral recumbency. Under $2 \%$ lignocaine $\mathrm{HCl}$ local infiltration and cranial-epidural anaesthesia, right flank incision was made and the associated muscles were incised and on exploration of intestine, distended caecum (Figure 2) was observed and it was decompressed and sutured. Blind termination of spiral colon, distal loop and transverse colon were absent. The areolar tissue between caecum and terminal spiral colon was separated to mobilize the later to the dorsal area close to the descending colon followed with the use of retrograde passage of air lubricated flexible catheter up to the cranial sub-lumbar region progressively decreasing in size and ending blindly.

The descending colon was transacted at a distance of $15 \mathrm{~cm}$ from anal opening after transfixation of the small cranial blind end. The blind end of the mobilized spiral colon was opened. End-to-end and end-to-side anastomosis was performed by singles layer of simple interrupted suture pattern using no.1/0 chromic catgut. The intestinal forceps used to prevent spillage were released and patency checked. After lavage with normal saline, the intestines were replaced and the abdomen wall sutured routinely. Post operatively Amoxicillin - Cloxacillin @ 20mg/kg, Meloxicam @ $0.50 \mathrm{mg} / \mathrm{kg}$ and dextrose normal saline and ringers lactate were administered parentally daily for 7 days.

The principle clinical signs of the disease are depression, anorexia and abdominal distension. The time of onset of clinical signs may vary from 1-8 days (Smith et.al, 1991). However, in the present study, calf died 2 days after surgery. The age at presentation has never been associated with survival rate (Ducharme et.al, 1988) even with the increased degree of peritonitis.

Passage of flexible rubber tubing can be helpful in diagnosing atresia coli (constable et.al., 1989) and be limited to approximately $16 \mathrm{~cm}$ by the atretic segment in calves with atresia coli (Hoffsis and Brunner, 1975). In this case, the catheter passed $15 \mathrm{~cm}$. Some author reported the passage of flexible catheter into the rectum is inapproximate and risky. Surgical intervention is considered urgent because continuous 


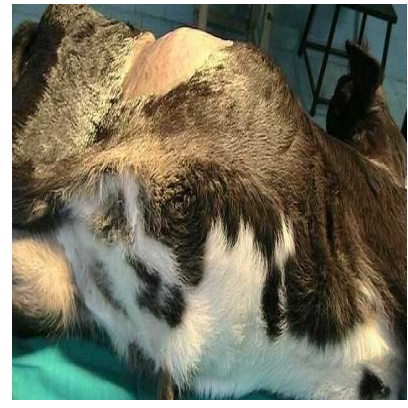

Figure-1. Distended Abdomen

dissention of large intestine leads to ischemia, necrosis, peritonitis and perforation (Constable et.al, 1989). There was a variable decrease in appetite and signs of colic and depression appeared usually after one day (Durmus, 2009). Abdominal distension during physical examination in this study is in agreement with the findings of Tulleners, 1989 and Sarserled, 2004. Pink and plash sounds were heard during simultaneous auscultation and percussion of the abdomen in accordance with the findings reported by Matins et.al, 1995. The long term survival rate of surgically treated animals depends largely on the site of the intestinal atresia and the surgical technique used (Matins et al., 1995). Pregnancy diagnosis by palpating the amniotic sac during the period of principle organogenesis between 36 to 42 days of

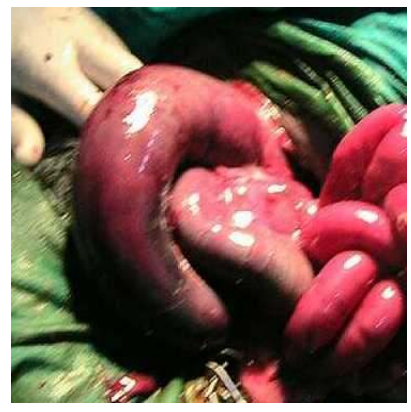

Figure-2. Dilated Caecum

gestation has been suggested to cause intestinal atresia in cattle (Brenner and Orgd, 2003).

\section{References}

1. Brenner, J. and Orgad, U. (2003). J. Vet. Med. Sci., $65: 141$

2. Constable, P.D., Shanks, R.D., Huhn, J. and Morin, D.E. (1997). Theriogenology, $48: 775$.

3. Ducharme, N.G., et.al. (1988).Can Vet. J. $29: 818$.

4. Durmus A.S (2009). Congenital intestinal atresia in calves. Indian vet. J., 86:737-738.

5. Hoffsis, G.F. and Brunner,R.R(1975). Atresia coli in a twin calf. J.Am.vet.Med.Assoc. 171:433-434.

6. Matins, A., Gasthuys, F., Steenhaul, M. and De Moor, A. (1995). Vet. Record 136: 141.

7. Smith,D.F.,Durchamu,N.G.,Fubini, S.L.,Donawick,W.J and Erb,H.N (1991).Clinical Management and surgical repair of atresia coli in calves: 66 cases (1977-1988). J.Am.Vet.Med.Assoc.199:1185-1190.

8. Syed, M. and Shanks, R.D. (1992). J. Dairy Sci., 75 : 1105.

\footnotetext{
$* * * * * * * *$
} 